\title{
Alminnelige kontraktsrettslige prinsipper og kontraktstyper i
}

\author{
norsk rett
}

Ivar Alvik, professor dr. juris

Ivar Alvik (født 1974) er cand. jur. (UiO, 2000), M. jur. (University of Oxford, 2001) og dr. juris (UiO, 2007). Han har vært advokat i BA-HR (2001-2002) og Thommessen (2008-2011), og er $i$ dag professor i rettsvitenskap ved Universitetet i Oslo. Han er tilknyttet Nordisk Institutt for Sjørett hvor han har vært ansatt siden 2011.

I kontraktsrettslig argumentasjon henvises det ofte til begreper som alminnelige kontraktsrettslige eller obligasjonsrettslige prinsipper, alminnelige kontraktsregler, fundamentale kontraktsgrunnsetninger, eller lignende. Denne artikkelen diskuterer de alminnelige prinsippenes rolle i kontraktsretten, hva disse alminnelige prinsippene er eller bør anses å være, og hvilken vekt man bør legge på dem. Videre diskuteres forholdet mellom alminnelige prinsipper og spesielle kontraktstyper. Et hovedsynspunkt i artikkelen er at alminnelige prinsipper er og bør være en sentral del av kontraktsrettslig argumentasjon og metode. 


\section{Innledning 1}

Temaet for denne artikkelen er fenomenet alminnelige obligasjonsrettslige eller kontraktsrettslige prinsipper, og spørsmålet om hvilken rolle alminnelige prinsipper har og bør ha i kontraktsrettslige resonnementer. Nærmere bestemt er det som særlig skal problematiseres i det $f \varnothing$ lgende hva disse alminnelige prinsippene er, hvilket rettslig opphav de har og hvilken gjennomslagskraft de bør ha i individuelle kontrakter.

I mange kontinentaleuropeiske land bygger kontraktsretten og formueretten mer generelt på en systematisk lovfesting av alminnelige prinsipper i sivillovbøker utviklet med basis i romerretten. Her finner man også prinsipper for ulike kontraktstyper, utledet fra og systematisk innordnet det overordnete prinsipielle og konseptuelle rammeverket. De viktigste eksemplene på slike systemer er den tyske sivillovboken (BGB) og den franske Code Civil, som kan sies å danne to hovedretninger innenfor den sivilrettslige romerrettstradisjonen («civil law»). ${ }^{2}$ En helt annen kontraktsrettslig tradisjon finner vi i den anglo-amerikanske «common law»-tradisjonen, som likevel ikke nødvendigvis bør anses som

\footnotetext{
${ }^{1}$ Artikkelen er løselig basert på deler av innledningskapitlene til min bok Fartøystjenesteleie, Oslo 2014 særlig s. 32 følgende, men er videre utviklet og bearbeidet. Takk til Trond Solvang og Erling Selvig for verdifulle innspill, innvendinger og kommentarer til et tidligere utkast. Alle synspunkter, svakheter, feil og unøyaktigheter står for min egen regning.

${ }^{2}$ Se nærmere Konrad Zweigert og Hein Kötz, Introduction to Comparative Law, oversatt av Tony Weir, 3. utgave, Oxford 1998 s. 68 følgende.
} 
noe mindre prinsipporientert enn den sivilrettslige. Istedenfor deduksjon fra abstrakte prinsipper særpreges imidlertid common law-tradisjonen av en mer pragmatisk, induktiv metode, hvor avtalefriheten - og hva partene rent faktisk har avtalt - er det helt sentrale utgangspunktet. Men dette forhindrer ikke at kontraktsretten under common law også i betydelig grad har sine prinsipper. Forskjellen er at det som kan anses som bærende prinsipper her har grodd frem mer gradvis, og stadig løpende utvikles, gjennom en mer induktiv slutningsprosess med utgangspunkt i enkeltavgjørelser og kommersielle hensyn.

Norsk og nordisk kontraktsrett ligger på mange måter et sted imellom disse tradisjonene. Vår kontraktsrett er i større utstrekning enn det som er og har vært tilfellet i engelsk rett lovregulert. Men i motsetning til sivilrettstradisjonen er det meste av vår lovgivning kasuistisk regulering av spesifikke avtaletyper, noe som også har medført at en rekke viktige avtaletyper ikke er eller har vært gjenstand for lovgivning. Her har imidlertid den generelle oppfatningen i nordisk rett vært at også slike kontrakter er underlagt den såkalte «bakgrunnsretten», ${ }^{3}$ som ofte har blitt sammenfattet i et begrep om alminnelig

\footnotetext{
${ }^{3}$ Når jeg her viser til «bakgrunnsretten» tilstreber jeg som utgangspunkt ikke noe høyere presisjonsnivå enn at jeg mener å betegne alle rettslige normer med potensiell anvendelse i et gitt kontraktsforhold som ikke har noen forankring i partenes spesifikke forhold. Dette tilsvarer så vidt jeg kan se i hovedsak Høgbergs begrep om bakgrunnsretten som «rettsstoff uten spesifikk partstilknytning», som danner grunnlaget for det han omtaler som «harmoniserende tolkningsstil» jf. Alf Petter Høgberg, Kontraktstolkning: særlig om tolkningsstiler ved fortolkning av skriftlige kontrakter, Oslo 2006 s. 164.
} 
obligasjonsrett. ${ }^{4}$ Et nøkkelbegrep man ofte tyr til for å kunne si noe om innholdet av denne bakgrunnsretten er de såkalte alminnelige obligasjonsrettslige eller kontraktsrettslige prinsipper. ${ }^{5}$ Samtidig virker det ikke å være noen helt alminnelig enighet $\mathrm{i}$ kontraktsrettslitteraturen om hva dette fenomenet er, og hvilken betydning det har eller bør ha i rettslig argumentasjon. I praksis kompliseres dette også av at det grunnleggende prinsippet i kontraktsretten er avtalefriheten, som tilsier at det alltid (det vil si innenfor rammene for avtalefriheten) er hva partene rent faktisk har avtalt som må legges til grunn,

\footnotetext{
${ }^{4}$ Man har også gjerne skilt mellom alminnelig og spesiell obligasjonsrett, men her er det et eget spørsmål om dette er et særlig meningsfylt skille, noe som særlig synes å ha blitt problematisert i dansk rett. Om de flytende grenser mellom den alminnelige og spesielle obligasjonsrett, se for eksempel Mads Bryde Andersen og Joseph Lookofsky, Lærebok i Obligationsret I, 3. utgave, København 2010 s. 22 følgende.
}

${ }^{5}$ Et spørsmål for seg gjelder forholdet mellom obligasjonsrett og kontraktsrett. I eldre teori talte man gjerne om obligasjonsrett som læren om obligatoriske (i motsetning til tinglige) forpliktelser. Tanken er at mange problemer er felles for de fleste obligatoriske forpliktelser, og til dels også bør løses etter de samme eller beslektede regler og prinsipper, typisk alt som har med oppfyllelse å gjøre. I praksis gjaldt likevel hoveddelen av obligasjonsretten kontraktsrettslige forpliktelser. I det følgende er det prinsipper som gjelder kontrakter jeg har i tankene, og jeg benytter dermed hovedsakelig benevnelsen alminnelige kontraktsrettslige prinsipper, jf. også slik for eksempel Erling Selvig, "Kontraktsretten», i Knophs oversikt over norsk rett, 10. utgave, Oslo 1993 s. 298, særlig på s. 315 og Erling Selvig, «Obligasjonsrett», i Knophs oversikt over norsk rett, 10. utgave Oslo 1993 s. 687 følgende. I andre nyere fremstillinger brukes fortsatt betegnelsen obligasjonsrett og alminnelige obligasjonsrettslige prinsipper (eller lignende), uten at det er grunn til å se i dette noen synderlig realitetsforskjell med hensyn til fenomenet som omtales, se Viggo Hagstrøm, Obligasjonsrett, 2. utgave, Oslo 2011 s. 75 og Jo Hov og Alf Petter Høgberg, Obligasjonsrett, 2. utgave, Oslo 2017 s. 31 følgende. 
uansett hva som følger av bakgrunnsretten. Dette betyr at kontraktsrettslige prinsipper alltid må ses i lys av og anvendes under hensyn til partsspesifikke forutsetninger i det enkelte avtaleforhold. Normalt vil det også i noen grad kunne være en glidende overgang mellom det å utgi noe som et rent prinsipielt synspunkt forankret i bakgrunnsretten, og det å utgi det som en betraktning om hvordan ordlyden i en avtale rent konkret bør forstås ut fra hva som fremstår som en god og rimelig regel for partene i det aktuelle tilfellet.

I mer prinsipiell forstand kan man si at formålet med mye av den kontraktsrettslige bakgrunnsretten er å gi utfyllende regler så å si i forlengelsen av partenes intensjon. ${ }^{6}$ Bakgrunnsretten gjør det mulig å inngå avtaler uten noen omfattende kontraktsregulering, nettopp i visshet om at det finnes en bakgrunnsrett. Dette gjelder særlig der bakgrunnsretten er lovregulert, men også utenfor. For eksempel er det de færreste som kvier seg for å ta drosje, gå til frisøren, spise på restaurant eller overnatte på hotell, eller som insisterer på å fremforhandle generelle vilkår før man lar seg betjene på denne måten, selv om vi ikke har noen lovregulering av drosje-, frisør- restaurant eller hotelltjenester. Når vi skal formulere bakgrunnsretten for slike kontrakter står alminnelige kontraktsrettslige prinsipper sentralt.

\footnotetext{
${ }^{6}$ Formuleringen har jeg fra Trond Solvang.
} 
Ikke alle er enige i at det å formulere alminnelige kontraktsrettslige prinsipper er særlig fruktbart. ${ }^{7}$ Noe av formålet med denne artikkelen er dermed også å fors $\varnothing$ ke å problematisere nærmere noen innvendinger mot å oppstille slike prinsipper og benytte dem i juridisk argumentasjon. Typiske innvendinger er gjerne at dette forutsetter et så høyt abstraksjonsnivå at prinsippene blir vage og ubestemte, eller at det å basere seg på alminnelige prinsipper ikke yter rettferdighet til det brokete og komplekse rettskildebildet som gjerne knytter seg til en aktuell problemstilling. I kontraktsretten forsterkes en slik innvending som allerede nevnt av at det overordnede prinsippet er avtalefriheten, og at det avgjørende for å finne løsninger på konkrete rettslige problemer normalt i siste instans er hva partene har (eller kan anses å ha) avtalt. I forlengelsen av dette kan man hevde at bakgrunnsretten for en gitt kontraktstype, uansett muligheten for å operere med prinsipper, i alle fall ikke bør ha noen særlig stor praktisk betydning der kontraktene selv er omfattende og detaljerte, og endatil kanskje selv tilstreber å regulere de fleste spørsmål uttømmende. Mange kontrakter vil være basert på detaljerte, bransjeforhandlete standardvilkår, som tilsikter å Iøse de fleste spørsmål som kan oppstå for de aktuelle kontraktene. Innvendingen vil gjerne være at hvis man her går langt i å supplere kontrakten med bakgrunnsretten eller alminnelige prinsipper, vil det gå på bekostning av det hensynet til forutberegnelighet som er avgjørende i kommersielle kontraktsforhold.

\footnotetext{
${ }^{7}$ Skeptisk er for eksempel Kåre Lilleholt, Kontraktsrett og obligasjonsrett, Oslo 2017 s. 29, se også nærmere nedenfor.
} 
Nedenfor hevder jeg at ingen av disse innvendingene gir gode argumenter mot at alminnelige kontraktsrettslige prinsipper anses som en helt sentral tankefigur i kontraktsretten, som nesten alltid må tas i betraktning som et relevant og noen ganger avgjørende argument ved tolkning og anvendelse av konkrete kontrakter. En viktig presisering er at jeg med prinsipper her mener normer med retningslinjekarakter, og ikke regler som fremtvinger bestemte løsninger i de situasjonene de kommer til anvendelse. ${ }^{8} \mid$ mer tradisjonell rettskildeterminologi kan alminnelige kontraktsrettslige prinsipper ses som en disiplinerende tankemodell for å resonnere rundt hva som normalt vil utgjøre relevante, reelle hensyn i individuelle kontraktsforhold. ${ }^{9}$ Men som jeg kommer tilbake til ligger det også noe mer i et begrep om prinsipper, i det at det forutsetter en systemforankring som gir de kontraktsrettslige prinsippene en mer positivrettslig eller objektiv karakter enn det vi normalt forbinder med reelle hensyn. Videre vil de kontraktsrettslige prinsippene som regel ikke bare identifisere bestemte hensyn som relevante, men også være retningsgivende for avveiningen av ulike hensyn.

Jeg skal i det følgende først si noe om bruken av begrepet alminnelige prinsipper i norsk og nordisk kontraktsrettslitteratur og den utviklingen vi har sett internasjonalt med $\varnothing$ kt fokus på

\footnotetext{
${ }^{8}$ Se om retningslinjer særlig Nils Kristian Sundby, Om normer, Oslo 1974 s. 190 følgende. Sundby er skeptisk til begrepet prinsipp, som han mener er flertydig, og velger derfor å benytte termen retningslinjer. Innenfor kontrakts- og obligasjonsretten er imidlertid begrepet prinsipp så innarbeidet at det ville bli kunstig å benytte et annet begrep.

${ }^{9}$ Slik også Trond Solvang, Forsinkelse i havn: risikofordeling ved reisebefraktning, Oslo 2009 s. 798.
} 
overgripende kontraktsrettsprinsipper (punkt 2). Jeg skal så problematisere noe nærmere betydningen av alminnelige prinsipper i tilknytning til ulike, spesielle kontraktstyper (punkt 3), før jeg sier litt mer om det vi kan kalle naturlige kontraktstyper som et utgangspunkt for prinsipielle synspunkter (punkt 4). Deretter diskuterer jeg nærmere hva vi rimeligvis kan og bør mene med et begrep om alminnelige kontraktsrettslige prinsipper (punkt 5), før jeg drøfter hvordan vi rent metodisk kan utlede hvilke alminnelige prinsipper som gjelder for en gitt kontraktstype på ulovfestet grunnlag, særlig betydningen av analogislutninger som utgangspunkt for å oppstille prinsipper (punkt 6). Endelig drøfter jeg noen mulige innvendinger mot å legge vekt på alminnelige prinsipper i individuelle kontrakter som foregir å være uttømmende (punkt 7).

\section{Ulike synspunkter på alminnelige prinsipper og deres betydning}

Mer enn andre rettsfelter er kontraktsretten (sammen med formueretten mer generelt) et felles-europeisk kulturprodukt, som har vokst frem og blitt finslipt gjennom lang historisk utvikling. «[P]å formuerettens område lever [vi] under rekker av rettsregler som i vesentlig samme form var anerkjent på en tid da Magnus Lagabøtes lover ennu ikke var skrevet», som Stang formulerer det i sin Innledning til formueretten. ${ }^{10}$ En nærmest organisk utvikling gjennom et par tusen år har krystallisert seg i enkelte underliggende konsepter og prinsipper som vi finner igjen, riktignok med nasjonale særtrekk og i ulike former, i de fleste lands

\footnotetext{
${ }^{10}$ Fredrik Stang, Innledning til formueretten, 3. utgave, Oslo 1935 s. 18-19.
} 
rettssystemer. ${ }^{11}$ Noen har kanskje latt fellestrekkene overskygge forskjellene i for stor grad, som Platou når han skriver:

«Der gives ingen specifik norsk Privatrettens alm. Del. Grundlaget for Privatrettens alm. Del er lagt af de romerske Jurister, og paa dette Grundlag har de følgende Tiders Retsudvikling bygget i alle Lande. Vi finder derfor, at trods alle Afvigelser i de forskellige Landes perifere Detailregler er Kjærnen, de principielle Synspunkter, i det væsentlige fælles. $)^{12}$

Når det gjelder norsk kontraktsrett (eller obligasjonsrett om man vil) har den uomtvistelig sine nasjonale særtrekk, med røtter i en pragmatisk dansk-norsk tradisjon som går tilbake til den store danske rettsteoretikeren Anders Sandøe Ørsted. Også i denne tradisjonen står imidlertid utviklingen av alminnelige prinsipper og et begrep om en felles obligasjonsrett helt sentralt, i noen grad også influert av felles kontinentaleuropeisk romerrettstradisjon. ${ }^{13}$ Forestillingen om at ulike kontrakter og skyldforhold hører under en alminnelig obligasjonsrett, innebærer i seg selv en forståelse av at det finnes enkelte gjennomgående alminnelige prinsipper og konsepter av betydning for de fleste individuelle

\footnotetext{
${ }^{11}$ Se for eksempel Zweigert og Kötz, An Introduction to Comparative Law (1998), s. 323 følgende.

${ }^{12}$ Oscar Platou, Forelæsninger over udvalgte emner af privatrettens almindelige del, Kristiania 1914 i forordet s. III.

${ }^{13}$ Se Hagstrøm, Obligasjonsrett (2011), s. 82 følgende, Viggo Hagstrøm, «Den norske obligasjonsretts historie», Jussens Venner, 2003 s. 161-168 jf. også Dag Michalsen, Norsk rettstenkning etter 1800, Oslo 2013 s. 246 følgende.
} 
kontraktsforhold. ${ }^{14}$ Samtidig er det liten tvil om at den prinsipielle tenkningen som har preget dansk-norsk tradisjon, har en mer pragmatisk understrøm enn det som har vært tilfellet for eksempel i tysk tradisjon. ${ }^{15}$

I nyere tid, kanskje særlig under innflytelse av den nordiske rettsrealismens dominans fra 1970-tallet og helt frem til i dag, er det antagelig likevel riktig å si at store deler av norsk rettsteori er, og har vært, preget av en viss grunnleggende skepsis mot alminnelige prinsipper og konsepter, i alle fall som noe annet og mer enn pedagogisk sammenstilling og systematisering av enkeltregler. På 1970-tallet, da rettsrealismen stod som sterkest, ble det av flere teoretikere uttrykt skepsis mot i det hele tatt å se alminnelig obligasjonsrett som en egen rettsdisiplin, noe som bunnet i en grunnleggende skepsis til alminnelige prinsipper. ${ }^{16}$ Mens det både i rettspraksis, litteratur og forarbeider til kontraktsrettslig lovgivning ofte vises til alminnelige obligasjonsrettslige eller kontraktsrettslige prinsipper, er dette fortsatt i norsk teori et nokså omdiskutert fenomen. ${ }^{17}$ I sin nye bok Kontraktsrett og obligasjonsrett,

\footnotetext{
${ }^{14}$ At de som har bidratt sterkest til å utvikle en dansk-norsk obligasjonsrett, slik som Hallager, Lassen, Aubert og Ussing, og senere også Augdahl (se nærmere om dette Hagstrøm, Obligasjonsrett (2011), s. 82 følgende), ikke problematiserer eksistensen og betydningen av alminnelige prinsipper må nok derfor helst ses som utslag av at dette tas for gitt, heller enn som skepsis til fenomenet.

${ }^{15}$ Hagstrøm, Obligasjonsrett (2011), s. 82 følgende.

${ }^{16}$ Se Hagstrøm, Obligasjonsrett (2011), s. 30, med ytterligere henvisninger.

${ }^{17}$ I danske obligasjonsrettslige fremstillinger er man mindre opptatt av å problematisere betydningen av prinsipper, men man finner hyppig henvisninger til for eksempel «obligationsrettens almindelige
} 
skriver for eksempel Kåre Lilleholt om henvisninger i rettspraksis til alminnelige prinsipper eller rettsgrunnsetninger at «vi [kan] ha mistanke om at slike uttrykk skal vise til omstende av det slaget vi nettopp var inne på - omsynet til gode løysingar, medrekna omsynet til system og konsekvens, men da slik at vi skal få inntrykk av at løysinga byggjer på ein regel.»18 Ikke overraskende betoner han dermed en viss skepsis til om rettslitteraturen bør tilstrebe å formulere alminnelige prinsipper:

«Eit spørsmål for seg er om ei framstilling som denne skal prøve å formulere generelle reglar eller prinsipp. Helst skal vi vere varsame med det. I den grad det let seg gjere å finne slike normer, blir dei gjerne så vage at dei er til lita hjelp. ${ }^{19}$

Et pragmatisk, men mer velvillig syn på de alminnelige prinsippenes rolle finner vi hos Selvig, i hans fremstilling av «Kontraktsretten» i Knophs oversikt over norsk rett, 10. utgave. I utgangspunktet er det få alminnelige regler i kontraktsretten skriver han: «De fleste rettsregler om kontrakter gjelder således bare for bestemte kontraktstyper..${ }^{20}$ Men de fleste grundsætninger», jf. Bryde Andersen og Lookofsky, Lærebok i Obligationsret I (2010), s. 22; "generelle regler i betydningen grundsætninger», jf. Bernhard Gomard, Obligationsret, 1. del, 3. utgave, København 1998 s. 5; eller «grundhensyn», jf. Erik Werlauff, Skyldforhold: Obligationsrettens grundbegreper, København 2007 s. 23. For generell diskusjon se også, Jens Evald, «Om retsprincipper i formueretten» i Om retsprincipper, København 2004 s. $109-145$.

${ }^{18}$ Lilleholt, Kontraktsrett og obligasjonsrett (2017), s. 28.

${ }^{19}$ Lilleholt, Kontraktsrett og obligasjonsrett (2017), s. 29.

${ }^{20}$ Selvig, «Kontraktsretten» (1993), s. 315. 
kontraktslover har regler og systematikk som ligner hverandre, de har slektskapstrekk «som er vanlig hos søsken». ${ }^{21}$ Vi vil derfor «ganske ofte finne at en bestemt regeltype forekommer ganske ofte på ulike områder», og derfor «fremtrer ... som 'vanlig' eller 'alminnelig'».22 Betydningen av prinsipper man kan utlede på denne måten er imidlertid ikke primært at de gir entydige løsninger på bestemte rettsspørsmål, men at de kan «tjene som en god rettesnor når det for en annen kontraktstype viser seg å mangle sikre regler for løsningen av det tilsvarende spørsmål». ${ }^{23}$ Et sentralt aspekt hos Selvig er at det systematiske begrepet obligasjonsrett langt på vei er forlatt til fordel for kontraktsrett, ${ }^{24}$ noe som blant annet gir et klarere og mer realistisk bilde av det komplekse forholdet i kontraktsretten mellom konkret avtaletolkning og utfylling med alminnelige prinsipper, forutsetningsbetraktninger og lovgivning. ${ }^{25}$

Også Hov og Høgberg forutsetter at det de kaller «obligasjonsrettslige grunnprinsipper» har sentral betydning i kontraktsretten. ${ }^{26}$ De identifiserer også enkelte prinsipper som «kan

\footnotetext{
${ }^{21}$ Selvig, «Kontraktsretten» (1993), s. 315.

${ }^{22}$ Selvig, «Kontraktsretten» (1993), s. 315.

${ }^{23}$ Selvig, «Kontraktsretten» (1993), s. 316.

${ }^{24}$ Selvig, «Obligasjonsrett» (1993), s. 687 følgende, jf. også slik Kai Krüger, Norsk kontraktsrett, Bergen 1989 s. 3 følgende.

${ }^{25}$ Selvig, «Kontraktsretten» (1993), s. 535 følgende.

${ }^{26}$ Hov og Høgberg, Obligasjonsrett (2017), s. 31 følgende.
} 
kalles de sentrale grunnprinsipper på obligasjonsrettens område»; kontraktsfriheten, lojalitetsprinsippet, beskyttelse av god tro og formfrihet. ${ }^{27}$ Samtidig påpeker de, i likhet med Lilleholt, at det ofte kan være grunn til å utvise en viss skepsis når det vises til begreper som alminnelige kontraktsregler eller ulovfestede kontraktsgrunnsetninger, og forutsetningsvis da også alminnelige obligasjonsrettslige eller kontraktsrettslige prinsipper. Dette er begreper uten noe helt klart meningsinnhold, sies det, som ofte kan bli en kamuflasje for andre eller manglende begrunnelser for resultatet. ${ }^{28}$

Den som i nyere norsk (og antagelig nordisk) kontraktsrettslitteratur må sies å ha gått lengst i å utvikle alminnelige prinsipper som et praktisk verktøy i juridisk argumentasjon er Viggo Hagstrøm. ${ }^{29}$ Man kan nok si at Hagstrøm i betydelig grad bygger på og viderefører den systematiske tilnærmingen til obligasjonsretten som vi finner hos Augdahl, og som også har røtter tilbake til forfattere som Lassen, Stang, Ussing, Hallager og Aubert. ${ }^{30}$ Men han representerer også en metodisk videreutvikling av denne tradisjonen. Et gjennomgående trekk hos Hagstrøm, både i Obligasjonsretten og hans andre arbeider, er en systematisk tilnærming der til dels fragmenterte og noen ganger ulikt formulerte enkeltregler i lovgivning

\footnotetext{
${ }^{27}$ Hov og Høgberg, Obligasjonsrett (2017), s. 32 følgende.

${ }^{28}$ Hov og Høgberg, Obligasjonsrett (2017), s. 40-41.

${ }^{29}$ Om synet på alminnelige obligasjonsrettslige prinsipper som rettskilde, se generelt Hagstrøm, Obligasjonsrett (2011), s. 70 følgende.

${ }^{30}$ Hagstrøm, Obligasjonsrett (2011) s. 87, se også forordet s. 5-6.
} 
ses som utslag av mer alminnelige prinsipper med substansielt innhold. Prinsippets innhold fastlegges gjerne på grunnlag av en bredt anlagt metodisk tilnærming nokså løsrevet fra den enkelte lovregel, der fundamentale betraktninger (reelle hensyn), etablerte oppfatninger, «sedvanerett», rettspraksis, ordlyden i andre lover, samt uttalelser i forarbeider og eventuelle internasjonale kilder, danner grunnlag for å utlede et underliggende prinsipp. I Hagstrøms forståelse definerer prinsippet gjerne langt på vei innholdet i de ulike enkeltregler som anses som utslag av det, samt at det danner retningsgivende premisser for Iøsninger på områder uten lovregulering. ${ }^{31}$ Denne forståelsen innebærer at $\varnothing \mathrm{kt}$ lovgivningsaktivitet ikke har fortrengt de alminnelige prinsippenes og den alminnelige obligasjonsrettens betydning, tvert imot:

«Den betydelige lovgivningsinnsats og den betydelige kontraktsutviklingspraksis på et så bredt område og med så klare preferanser ved valg av modeller og løsninger, gir i dag et langt sikrere grunnlag enn man tidligere hadde for å oppstille alminnelige obligasjonsrettslige prinsipper pr. induksjon. Dette krever rettsdisiplinen alminnelig obligasjonsrett. $»^{32}$

\footnotetext{
${ }^{31}$ Se som eksempel analysen av kontrollansvaret, Hagstrøm, Obligasjonsrett (2011), s. 496 følgende. Noen ganger kan man nok også kritisere Hagstrøm for å la de antatte prinsippene overskygge mulige nyanser i analysen av enkeltregler, se som eksempel, om forholdet mellom ugyldighetsregelen i avtl. § 33 og reglene om opplysningsplikt som misligholdsgrunnlag, Ivar Alvik, «Endringskrav og ugyldighet ved forutsetningssvikt i komplekse tilvirkningskontrakter», i Ugyldighet i privatretten - minnebok for Viggo Hagstrøm, Bergen 2016
s. $21-48$.

32 Hagstrøm, Obligasjonsrett (2011), s. 31.
} 
At alminnelige kontraktsrettslige prinsipper anses som et utgangspunkt for kontraktsrettslig argumentasjon i praksis kan det heller ikke være særlig tvil om. Dette viser blant annet hyppigheten av henvisninger i Høyesteretts praksis de senere år, ${ }^{33}$ og kanskje også en mer gjennomgående tendens i praksis til å argumentere mer prinsipielt i dag enn tidligere også på andre rettsområder. ${ }^{34}$

I kontraktsretten forsterkes denne tendensen av et omfattende internasjonalt arbeid for kodifisering og uniformering av universelle eller felles kontraktsrettsprinsipper på tvers av nasjonale kontraktsrettstradisjoner, særlig de siste $20-30$ år. ${ }^{35}$ Viktigst her er UNIDROIT prinsippene for internasjonale kommersielle kontrakter. ${ }^{36}$ UNIDROIT er en internasjonal

${ }^{33}$ Se Hov og Høgberg, Obligasjonsrett (2017), s. 31-32. I tillegg til den praksis som vises til der kunne man også vise til flere andre og nyere dommer der alminnelige kontraktsrettslige prinsipper enten har blitt vist til eller implisitt synes å ha vært retningsgivende for løsningen, se for eksempel HR-2017-515-A, HR-2016-1447-A, Rt. 2014 s. 520, Rt. 2012 s. 1779 og også Skoghøys dissenterende votum i Rt. 2008 s. 537.

${ }^{34}$ Jf. slik for eksempel Hans Petter Graver, «I prinsippet prinsipiell - om rettsprinsipper» Tidsskrift for Rettsvitenskap, 2006 s. 189-221, på s. 189 følgende og Erling Selvig, «Kontraktsutfylling og legalitetsprinsipp. Metodeproblemer i kontrakts- og forvaltningsrettens grenseland» i Rettsteori og rettsliv: Festskrift til Carsten Smith, Oslo 2002 s. 703-720, s. 704.

${ }^{35} \mathrm{FN}$-konvensjonen om internasjonale løsørekjøp (CISG-konvensjonen), som gir felles regler for internasjonale kjøp, blir ofte trukket frem som en milepæl i arbeidet mot en internasjonalisering av kontraktsretten, se Hagstrøm, Obligasjonsrett (2011), s. 51.

\footnotetext{
${ }^{36}$ Nyeste versjon er UNIDROIT Principles of International Commercial Contracts (2016). Første versjon av prinsippene kom i 1994, og de har senere blitt revidert i 2004, 2010 og nå sist i 2016.
} 
organisasjon med stater som medlemmer og en formell, rettslig forankring i en traktat som gir betydelig politisk autoritet og legitimitet. ${ }^{37}$ Prinsippene er utarbeidet med basis i konsepter som er felles for de fleste nasjonale kontraktsrettstradisjoner, samtidig som de er ment å være en videreutvikling av prinsipper særlig egnet for internasjonale kontraktsforhold. ${ }^{38}$ De såkalte Principles of European Contract Law (PECL) representerer en tilsvarende kodifikasjon (eller «restatement») av kontraktsretten på europeisk nivå. Her har vi også fått det såkalte Draft Common Frame of Reference, som er et EU-initiativ og som har betydning langt utover kontrakts- og obligasjonsretten i snever forstand. ${ }^{39}$ Et fellestrekk ved disse internasjonale kodifikasjonene er nettopp at fokus flyttes fra det Platou omtalte som «alle Afvigelser i de forskellige Landes perifere Detailregler» til «Kjærnen, de principielle Synspunkter». ${ }^{40}$ At det i økende grad ses hen til internasjonale kontraktsrettsprinsipper,

\footnotetext{
${ }^{37}$ Organisasjonens fulle navn er UNIDROIT International Institute for Unification of Private Law, den har 63 medlemsstater, deriblant Norge, og den har hovedkvarter i Roma.

38 Jf. forordet til den første versjonen av prinsippene fra 1994: «For the most part the UNIDROIT Principles reflect concepts to be found in many, if not all, legal systems. Since however the UNIDROIT Principles are intended to provide a system of rules especially tailored to the needs of international commercial transactions, they also embody what are perceived to be the best solutions, even if still not yet generally adopted."

${ }^{39}$ For nærmere redegjørelse, se Hagstrøm, Obligasjonsrett (2011), s. 61 følgende.

${ }^{40}$ Platou, Forelæsninger over udvalgte emner af privatrettens almindelige del (1914), i forordet s. III.
} 
særlig UNIDROIT-prinsippene, er en tendens som også synes å ha fått et visst gjennomslag i norsk rettspraksis de senere år. ${ }^{41}$

\section{Alminnelige prinsipper og spesielle kontraktstyper}

Med alminnelige kontraktsrettslige prinsipper sikter jeg i denne artikkelen til noe mer enn det man kunne betegnet som «kontraktsrettens alminnelige del»; altså den del av kontraktsretten som er felles for og gjelder alle eller de fleste kontrakter. Når vi beveger oss inn i bakgrunnsretten for bestemte kontraktstyper er prinsippene ofte ikke «alminnelige» på samme måte som den alminnelige obligasjonsretten er det. ${ }^{42}$ Men også for spesielle kontraktstyper består bakgrunnsretten i stor grad av det jeg kaller alminnelige prinsipper. Et prinsipp er i denne forstand «alminnelig» etter mitt syn ikke fordi det må anses å gjelde for alle eller de fleste kontrakter, men på grunn av det vi kan kalle et genealogisk aspekt; ${ }^{43}$ at den aktuelle normen på en eller annen måte er organisk forbundet med og nedstammer fra

41 Jf. Rt. 2014 s. 100, avsnitt 37, LB-2009-193783, LH-2009-62599 og LB-2008-46604.

${ }^{42}$ Om de flytende grenser mellom den alminnelige og spesielle obligasjonsrett, se for eksempel Bryde Andersen og Lookofsky, Lærebok i Obligationsret I (2010), s. 22.

${ }^{43}$ For en nærmere problematisering av de alminnelige prinsippenes genealogi eller opphav, se også Hov og Høgberg, Obligasjonsrett (2017), s. 31, som reiser spørsmålet om et prinsipp alltid må ha et rettskildegrunnlag eller om det kan være riktigere å si at det er prinsippet som er opphav til rettskildene vi forankrer det i. Antagelig har vel ikke dette spørsmålet noen bedre løsning enn spørsmålet om høna eller egget kom først, noe som også synes å være Hov og Høgbergs konklusjon, jf. s. 32. 
fundamentale prinsipper i kontraktsretten, som er felles for alle eller de fleste kontrakter. ${ }^{44}$ Et bilde på kontraktsretten kan være som et stort tre med mange forgreninger, der man har noen helt alminnelige prinsipper som er felles for alle kontrakter og som utgjør grunnstammen og røttene, og der forgreninger ut fra stammen utgjør de ulike kontraktstypene. Eksempler på helt alminnelige prinsipper som gjelder for de fleste kontraktstyper vil være avtalefriheten og prinsippet om at avtaler skal holdes, de avtalerettslige ugyldighetsreglene, lojalitetsprinsippet, det vi kan kalle gjensidighets- eller likevektsprinsippet og prinsippet (eller læren om) om bristende forutsetninger. Enhver kontrakt som inngås utgjør et skudd på allerede eksisterende forgreninger, samtidig som den er forbundet med de fundamentale prinsippene som utgjør kontraktsrettens grunnstamme. Det er ingen egentlige motsetninger her mellom det alminnelige og det spesielle; grenene er alle forbundet med stammen og har elementer av det alminnelige i seg, om enn i varierende grad.

\footnotetext{
${ }^{44}$ Regler uten opprinnelse i partenes kontraktsforhold som ikke har noen slik alminnelig forankring vil kunne være regler som enten bygger på spesielle kutymer som gjelder for den aktuelle kontraktstypen, eller på lovregulering utformet for å tjene særlige hensyn, for eksempel i forbrukerforhold eller arbeidsavtaler hvor enkeltheter i reguleringene vil være begrunnet i hensynet til beskyttelse av forbrukeren eller arbeidstakeren som den antatt svake part i kontraktsforholdet. I sjøretten vil for eksempel et spørsmål her være hvor langt lovreglene er basert på engelskrettslig inspirert kontraktspraksis, jf. for eksempel Amund Bjøranger Tørum, «Nordisk obligasjonsrett og dens betydning for norsk kontraktsrett», Tidsskrift for Rettsvitenskap, 2007 s. $563-$ 578, som på s. 567 fremholder at «[m]uligheten for å trekke transportavtalene inn i den mer alminnelige obligasjonsretten kompliseres ... av at de i stor grad lever sitt eget internasjonale liv».
} 
Et godt eksempel på dette kan være hvordan ulike kontraktsrettslige regler om vederlagsopptjening står i forbindelse med et mer grunnleggende prinsipp om gjensidighet i kontraktsforhold. ${ }^{45}$ Vi kan ta utgangspunkt i regelen i sjøloven § 392 om offhire ved tidsbefraktning, som i utgangspunktet fremstår som en regel som er nokså særegen for tidscertepartier, og som de fleste dermed også antagelig vil anse som en nokså perifer del av den alminnelige kontraktsretten. Regelen går ut på at det ikke skal betales vederlag, tidsfrakt, i perioder der det befraktede skipet er ute av drift som følge av omstendigheter som er bortfrakterens (rederens) risiko. Regelen er gammel og har blitt fortolket og utviklet i rettspraksis, som gir betydelig ytterligere presisering av hvilke omstendigheter som fører til offhire. ${ }^{46}$ Dette forhindrer ikke at regelen i sjølovens $§ 392$ kan ses som utslag av et mer alminnelig kontraktsrettslig prinsipp, nemlig prinsippet om ytelse mot ytelse eller gjensidighetsprinsippet. ${ }^{47}$ Regelen er dermed utslag av det samme prinsipp som reglene i kjøpsloven $\S \S 10$ og 49 (1) om at hver part kan holde tilbake sin ytelse dersom den andre

\footnotetext{
${ }^{45}$ Se generelt om gjensidighetsprinsippet, Selvig, «Kontraktsretten» (1993), s. 327 følgende, Werlauff, Skyldforhold: Obligationsrettens grundbegreper (2007), s. 43 følgende og Evald, «Om retsprincipper i formueretten» (2004), s. 115 (som omtaler det som ekvivalensprinsippet). Se også Solvang, Forsinkelse i havn (2009), s. 194 følgende.

${ }^{46}$ I praksis vil som regel også det enkelte certeparti inneholde en egen offhire-klausul med detaljert oppregning av hvilke omstendigheter som fører til offhire, særlig engelske certepartiformularer går langt i denne retning.

${ }^{47}$ Se nærmere Alvik, Fartøystjenesteleie (2014), s. 152 følgende og Solvang, Forsinkelse i havn (2009), s. 225 følgende.
} 
part ikke oppfyller. Både i kjøp og i tidsbefraktning er forutsetningen for opptjeningen av vederlaget at yteren oppfyller sin egen ytelse. Samtidig vil yteren fortsatt ha krav på vederlaget dersom hans egen ytelse forhindres av forhold bestilleren har risikoen for. ${ }^{48}$ Man kan si at gjensidighetsprinsippet i alminnelighet forutsetter en generell risikoreservasjon. Det er kun der det foreligger mislighold, med andre ord der den ene parts ytelse ikke blir oppfylt som følge av forhold han har risikoen for, at balansen i kontraktsforholdet forrykkes på en måte som gir den annen part rett til å tilbakeholde sin ytelse, heve eller kreve prisavslag. ${ }^{49}$ Vi kan også se hvordan den samme gjensidighetsforutsetningen gjør seg gjeldende i kontraktsforhold som er av en helt annen type enn kjøp og tidsbefraktning, nemlig entreprisekontrakter. La oss anta at det oppstår en oppfyllelseshindring som byggherren, bestilleren, har risikoen for. I kjøp og ved tidsbefraktning var konsekvensen av at bestilleren hadde risikoen primært at yteren fortsatt kunne kreve vederlaget. I entrepriseforhold kommer det imidlertid inn en tilleggsforutsetning, nemlig at yteren har påtatt seg å frembringe et bestemt arbeidsresultat (for eksempel et hus) og at dette skal ferdigstilles uansett. Dersom en hindring gjør at det blir vanskeligere eller dyrere å utføre arbeidet kan ikke yteren, altså byggmesteren eller entreprenøren, av den grunn la være å gjøre arbeidet. Hvis jeg har bestilt en entreprenør til å bygge et hus for meg, og det viser seg at det er mer

\footnotetext{
${ }^{48}$ Jf. sjøl. § 392 som lar dette avhenge av om tidstapet skyldes «tidsbortfrakterens forhold», og kjøpsloven §§ 51 og 52, som fastsetter at selger kan kreve betaling selv om tingen ikke blir levert hvis dette skyldes at kjøperen ikke «oppfyller sine øvrige plikter etter avtalen eller loven».

${ }^{49}$ Hagstrøm, Obligasjonsrett (2011), s. 327.
} 
fjell i grunnen enn vi hadde forutsatt, slik at det er nødvendig med sprengningsarbeider istedenfor kun gravemaskin, ville jeg med god grunn bli skuffet hvis entreprenøren etter halvgjort arbeid erklærer at han ikke hadde tatt høyde for dette og dermed ikke ser seg i stand til å ferdigstille huset. Det kan likevel tenkes at vi utfra en tolkning av kontrakten kommer til at det å utføre sprengningsarbeider ikke inngår i den forpliktelsen entrepren $\varnothing$ ren har påtatt seg. ${ }^{50}$ Når forholdene viser seg å være slik at entreprenøren må utføre sprengningsarbeider, forrykker imidlertid det gjensidigheten i kontraktsforholdet. Entreprenøren må utføre et arbeid som er mer omfattende, vanskeligere og dyrere enn det han opprinnelig forpliktet seg til. Konsekvensen av dette er at han gjennomgående vil ha et krav på tilleggsbetaling, nettopp for å gjenopprette gjensidigheten i kontraktsforholdet. Forbindelsen med en grunnleggende gjensidighetsforutsetning gjør at entrepren $\varnothing$ rens krav på tilleggsbetaling kan ses som en konsekvens av de samme grunnleggende betraktninger som i sjøretten kan gi tidsbefrakteren krav på å anse skipet offhire, og i kjøpsretten kan gi kjøperen krav på å tilbakeholde betalingen (dog i de to sistnevnte tilfellene med motsatt fortegn). De ulike reglene kan ses som ulike forgreninger fra en felles stamme, som på et vis også gir seg selv ut fra det enkelte kontraktsforholds egenart, når man tar utgangspunkt i grunnprinsippet.

\footnotetext{
${ }^{50}$ Dette er i samsvar med det som kan anses som en etablert hovedregel i entrepriseforhold, nemlig at «uforutsette grunnforhold er byggherrens risiko» jf. Viggo Hagstrøm og Herman Bruserud, Entrepriserett, Oslo 2014 s. 208.
} 


\section{Naturlige kontraktstyper}

I eldre nordisk kontraktsrettstradisjon betegnet man gjerne grenene på treet, bakgrunnsretten knyttet til bestemte kontraktstyper, som kontraktenes naturalia negotii. ${ }^{51}$ Ideen var at det for hver definerte kontraktstype gjelder et sett utfyllende rettsregler som kommer til anvendelse der partene ikke har avtalt noe annet. Fastleggelse av bakgrunnsretten forutsetter i samsvar med dette i første omgang en klassifikasjon av kontraktstypen på grunnlag av den enkelte avtales essensialia negotii, som med Høgberg kan betegnes som «den del av kontraktens innhold som fastlegger dens 'natur', 'essens' eller 'vesen' i relasjon til de ulike former for naturalia negotii.. ${ }^{52}$

I de fleste kontraktslover vil en typeklassifisering være avgjørende for om loven kommer til anvendelse. Også standardvilkår vil normalt bygge på visse mer eller mindre bestemte forutsetninger om hvilken type kontrakter de er ment anvendt på, men her vil anvendelsen av vilkårene i utgangspunktet avhenge av om de er avtalt i det enkelte tilfelle. Lover og standardvilkår oppstiller imidlertid ofte litt andre skillelinjer enn det som går på kontraktenes natur i mer prinsipiell forstand. For eksempel har vi ulike lover for kjøp av ting

\footnotetext{
${ }^{51}$ Jf. Henry Ussing, Aftaler, 3. utgave, København 1950 s. 434-435: «Alle de Regler, der kommer til Anvendelse paa en retshandelstype, forsaavidt de ikke er fraveget ved Retshandelen, kalder man naturalia negotii.» Høgberg, Kontraktstolkning: særlig om tolkningsstiler ved fortolkning av skriftlige kontrakter (2006), s. 169 omtaler dette som kontraktstypeløsninger.

${ }^{52} \mathrm{H} \emptyset$ gberg, Kontraktstolkning: særlig om tolkningsstiler ved fortolkning av skriftlige kontrakter (2006), s. 169 følgende.
} 
og kjøp av eiendom, selv om vi i prinsipiell forstand må kunne anse begge som likeartede og omfattet av den samme naturlige kontraktstypen - kjøp. Det vil naturligvis ofte være gode grunner til å skille mellom ulike ytelser, næringer og livsområder, eller mellom kontrakter som inngås i næring på den ene side og forbrukerkontrakter på den annen. Man kan da mer presist gi regler som passer for de faktiske hensyn og forutsetninger som gjelder på det aktuelle livsområdet. ${ }^{53}$ For eksempel kan det være ganske store forskjeller på hvilke hensyn som normalt gjør seg gjeldende ved kjøp og salg av henholdsvis skip og fritidsbåter, noe som kan begrunne hvorfor dette normalt vil være underlagt ulik regulering selv om det er tale om kontrakter som prinsipielt er likeartet.

Også for kontrakter som ikke er lovregulert vil en klassifisering av kontraktstype kunne ha betydning for hvilke prinsipper som må anses å komme til anvendelse. Når vi skal forsøke å si noe om hvilke prinsipper som følger av kontraktens natur, kan imidlertid dette kreve en annen og mer abstrakt kategorisering som følger av arten av de forpliktelser kontrakten gjelder. Dette kan vi omtale som naturlige kontraktstyper. ${ }^{54}$ Litt forenklet kan vi kanskje si at de tradisjonelt viktigste naturlige kontraktstypene vi har er kjøp, leie og to ulike typer av tjenestekontrakter - tjenesteleie og verksleie, som jeg jeg kommer tilbake til nedenfor.

\footnotetext{
${ }^{53}$ Mads Henry Andenæs, Kontraktsvilkår, Oslo 1989, på s. 11, omtaler dette som «kontraktstyper i faktisk forstand».

${ }^{54}$ Dette samsvarer med det Andenæs, Kontraktsvilkår (1989), på s. 10, omtaler som «kontraktstyper i rettslig forstand».
} 
Innenfor en «kontraktstype i faktisk forstand ${ }^{55}$ som befraktningsavtaler kan vi for eksempel skille mellom to vesensforskjellige undertyper - tidsbefraktning og reisebefraktning. Skillet mellom disse to kontraktstypene går ikke på hva yteren - bortfrakteren - rent faktisk eller fysisk har påtatt seg å gjøre. I begge tilfeller skal han utføre frakt mellom ulike destinasjoner med et skip som han stiller til rådighet for bestilleren. Forskjellen går på hvilken rettslig forpliktelse han har påtatt seg. Ved reisebefraktning har han påtatt seg å utføre en bestemt reise til en gitt pris. ${ }^{56}$ Hvis det oppstår hindringer underveis, slik at reisen tar lengre tid enn vanlig, kan han fortsatt bare kreve den avtalte prisen. Bortfrakteren har dermed tids- eller kostnadsrisikoen. Ved tidsbefraktning derimot påtar bortfrakteren seg å stille skipet, med mannskap og fortsatt under hans egen operative kommando, til befrakterens disposisjon $\mathrm{i}$ en gitt tidsperiode. ${ }^{57}$ I dette tilfellet vil det ikke ha noe å si for ham om en reise tar lengre tid enn vanlig. Han får uansett betalt for hver dag skipet står til befrakterens rådighet. Her er det befrakteren som har tids-/kostnadsrisikoen.

Utfra slike abstrakte egenskaper ved forpliktelsen kan det være prinsipielle fellestrekk mellom kontrakter som i faktisk forstand er ganske ulike. For eksempel er så forskjellige kontraktstyper som reisebefraktning og entreprise nært prinsipielt beslektet. Begge tilhører den kategorien kontrakter som tradisjonelt har vært benevnt verksleie. Et godt eksempel på

\footnotetext{
${ }^{55}$ Andenæs, Kontraktsvilkår (1989), s. 11.

${ }^{56}$ Jf. Thor Falkanger og Hans Jacob Bull, Sjørett, 8. utgave, Oslo 2016 s. 261.

${ }^{57}$ Falkanger og Bull, Sjørett (2016), s. 262.
} 
dette er det nære slektskapet mellom entrepriserettens regler om tilleggsbetaling og befraktningsrettens regler om liggetidsbetaling ved forsinket opphold i havn. ${ }^{58}$

Tidsbefraktning må derimot prinsipielt sett anses å falle inn under kategorien tjenesteleie, eller det man kan kalle gjenstandsbasert tjenesteleie. ${ }^{59}$ Siden både reise- og tidsbefraktning er gjenstandsbaserte tjenesteytelser - de forutsetter oppfyllelse med et skip - har de også et visst slektskap med leie.

Utgangspunktet for å klassifisere kontraktstyper på denne måten i prinsipiell forstand vil normalt være den abstrakte karakter av den forpliktelse realyteren, den som skal prestere noe annet enn penger, påtar seg under kontrakten. ${ }^{60}$ Innenfor den rammen de prinsipielle utgangspunkter for kontraktstypen utgjør, vil det naturligvis være betydelig rom for ulike regler. Hva ytelsen rent fysisk går ut på, samt forutsetninger innenfor ulike bransjer, livs- og næringsområder vil her spille inn. Det kan også være betydelig variasjon mellom ulike kontraktstyper når det gjelder bakgrunnsrettens utvikling og fasthet, om den er lovregulert, har vært gjenstand for utvikling i rettspraksis, sedvane og kutymer.

Et eksempel på forholdet mellom prinsipper som følger av kontraktstypens natur og slike historiske faktorer, er prinsippet om risikoens overgang ved kjøp, som altså er en av de

\footnotetext{
${ }^{58}$ Se nærmere Trond Solvang, Forsinkelse i havn, (2009), s. 355 følgende.

${ }^{59}$ Alvik, Fartøystjenesteleie (2014), s. 57-58, inspirert av Krüger, Norsk kontraktsrett (1989), s. 197.

${ }^{60}$ Her kan man likevel selvfølgelig tenke seg at begge parters ytelser under kontrakten er realytelser, for eksempel ved avtaler om bytte eller ved ulike typer samarbeidsavtaler.
} 
klassiske naturlige kontraktstypene. Kjøp kjennetegnes ved at avtalen går ut på å overføre eiendomsretten til det som er objektet for avtalen mot et vederlag. Utfra dette kan man si at det følger av kjøpsavtalens natur at det normalt skal skje en risikoovergang. Men man kan fint tenke seg ulike tidspunkter for når risikoovergangen skal skje, og man kan også tenke seg at dette bør avhenge av hva som er objektet for kjøpsavtalen. Således har man historisk og i ulike lands bakgrunnsrett eksempler på ulike utgangspunkter: både at risikoovergangen skjer når avtalen inngås (periculum emptoris) og når kjøperen får besittelsen over det solgte (periculum venditoris). Det grunnleggende prinsippet i norsk rett i dag er noe mer nyansert; risikoen går over på kjøperen når selgeren har oppfylt sin leveringsforpliktelse, det vil si gjort det han har forpliktet seg til for å overlate tingen til kjøper. ${ }^{61}$

Der en transaksjon ikke går ut på overføring av eiendomsretten, men kun besittelsen og rådigheten over avtaleobjektet i en begrenset tidsperiode, er det derimot tale om leie. Alt fra avtaler om husleie og tomtefeste til lisensiering av patenter, varemerker og andre immaterielle rettigheter kan ses som undergrupper av hovedkategorien leieavtaler. Forskjellen på leie og kjøp ligger i forpliktelsens karakter. Når det gjelder den rent fysiske ytelsen kan det noen ganger være vanskelig å skille det ene fra det andre. En

\footnotetext{
${ }^{61}$ Den tradisjonelle oppfatning har således vært at romerretten var basert på regelen om periculum emptoris, som vi også finner igjen i den gamle europeiske ius commune i middelalderen og i moderne engelsk og fransk rett. I norsk og nordisk rett, og også tysk rett, er utgangspunktet derimot at risikoen går over ved levering, jf. kjl. § 13 og BGB § 446, og jf. også Avhl. § 2-4. Se også nærmere Reinhard Zimmermann, The Law of Obligations: Roman Foundations of the Civil Law Tradition, Cape Town 1990 s. 281.
} 
tomtefesteavtale kan for eksempel innebære at festeren får tilnærmet den samme rådighet over eiendommen som en eier og retten kan også i prinsippet være evigvarende. Rettslig sett vil likevel tomtefeste være å anse som leie. Den prinsipielle forskjellen kan illustreres nettopp med spørsmålet om hvem som har risikoen for leieobjektet. Mens utgangspunktet ved kjøp er at det skal skje en risikoovergang må utgangspunktet ved leie være det motsatte; her beholder utleieren risikoen for objektet i den forstand at plikten til å betale leie opphører hvis objektet går til grunne. ${ }^{62}$ Selv om vi i dag kan lese dette ut av positive lovbestemmelser kan vi også se det som utslag av ulike naturalia negotii; ulike typeforutsetninger som springer ut av avtaleforholdenes essensielle natur.

Den tredje store gruppen kontrakter, som det, i alle fall i dag, hverken er naturlig å anse som kjøp eller leie, er tjenestekontraktene. Dette omfatter en stor gruppe nokså ulike kontrakter, som likevel alle kjennetegnes ved at kontraktens gjenstand ikke er en ting eller et definert eksisterende objekt, men en arbeids- eller tjenesteytelse; at noen utfører et arbeid eller en tjeneste, eller mer generelt stiller sin kapasitet eller arbeidskraft til disposisjon for en annen mot vederlag. Innenfor tjenesteavtalene skiller vi både i norsk rett og gammel sivilrettslig tradisjon mellom to prinsipielt vesensforskjellige typer avtaler; på den ene side den allerede nevnte kategorien verksleie og på den annen side arbeids- eller tjenesteleie. ${ }^{63}$ Roten til

\footnotetext{
${ }^{62}$ Jf. sjøl. §§ 350 og 393, og forutsetningsvis tomtefesteloven $\S 26$ og husleieloven $\S 5-7$.

${ }^{63}$ Se for eksempel L.M.B. Aubert, Den norske obligationsrets specielle del: bind II, 2.utgave, Kristiania 1905, s. 17.
} 
denne distinksjonen finner vi i romerretten, ${ }^{64}$ og de avledete tyske kategoriene werkvertrag og dienstvertrag.$^{65}$ Forskjellen mellom de to typene av tjenesteavtaler ligger i hva tjenesteyteren forplikter seg til. Ved tjenesteleie påtar han seg kun å stille sin arbeidskraft og sine ressurser til mottagerens rådighet, mens han ved verksleie påtar seg å produsere et bestemt arbeidsresultat. ${ }^{66}$

${ }^{64}$ Dette kan fremstå litt pussig i dag, men romerne anså også tjenestekontraktene som en form for leie, og skilte mellom tre undervarianter av det de anså som en og samme kontraktstype; leie av ting eller eiendom (locatio conductio rei), arbeids- eller tjenesteleie (locatio conductio operarum), og avtaler om utførelse av et bestemt arbeid eller et verk (locatio conductio operis). Fellestrekket var at alle avtalene handlet om noe som ble plassert under en annens rådighet. Locatio kommer av locare, som på latin betyr løselig å sette ut eller plassere noe under noens rådighet. Forskjellen ligger i hva dette noe, som var avtalens gjenstand, var definert som; om det var en bestemt ting eller eiendom, en persons arbeidskraft, eller et bestemt arbeid. Grunnen til å se på også det siste som en form for leie var at det her var selve arbeidet eller det $\emptyset$ nskede arbeidsresultatet som var «satt ut» eller overlatt til en annens rådighet. Med andre ord var det her tjenesteyteren som var leier, i den forstand at han var overgitt friheten til å råde over et arbeid for en annen, i motsetning til arbeidsavtalen hvor han kun leide ut sin arbeidskraft. Se nærmere Barry Nicholas, An Introduction to Roman Law, Oxford 1975 s. 171 følgende; og Zimmermann, The Law of Obligations: Roman Foundations of the Civil Law Tradition (1990), s. 338 følgende.

${ }^{65}$ Reglene for verksleie følger av BGB §§ 631-651, mens tjenesteleie er regulert i BGB §§ 611-630. Se nærmere Basil Markesinis, Hannes Unberath og Angus Johnston, The German Law of Contract: A Comparative Treatise, Oxford 2006 s. 154-157.

${ }^{66}$ Jf. for eksempel Henry Ussing, Dansk Obligationsret, Speciel Del, Bind II: Enkelte Kontrakter, København 1946, som behandler verksleie på s. 396-404 som en (på s. 396) «særlig Gruppe Arbeidskontrakter». Ussing skriver 
Det finnes også flere kontraktstyper som ikke faller innenfor noen av de hovedgruppene jeg har nevnt her. Blant disse er sammenslutningsavtaler, mellommannsavtaler, ulike former for låne- og finansieringsavtaler (som ikke er naturlig å gruppere sammen med leieavtalene fordi det som lånes ut er penger), avtaler om pant og sikkerhet etc. Det ville føre for langt å gå inn på alle disse her. Poenget har vært å vise hvordan det finnes prinsipielle skillelinjer mellom avtaler som gir grunnlag for å dele dem inn i nokså abstrakte kategorier av avtale- eller kontraktstyper, med konsekvenser for hva som er naturlige vilkår i avtaleforholdet. Vi kan si at kontraktstypene utgjør begrepsmessige strukturer som filtrerer mer alminnelige prinsipper og begreper som gjensidighet, lojalitet, risiko, mislighold osv. ned til enkelte kontrakter på bestemte måter. Samtidig gir dette grunnlag for å si noe om hvilke alminnelige prinsipper som gjelder for bestemte kontraktstyper. I mer tradisjonell rettskildeterminologi kan vi si at kontraktstypene gir grunnlag for å utlede bestemte reelle hensyn som vil gjelde i de aktuelle kontraktene utfra forholdets egenart eller natur. ${ }^{67} \mathrm{Vi}$ kan imidlertid like gjerne si

følgende om distinksjonen mellom verksleie og arbeidsleie: «Den herskende Opfattelse forstaar ved Værksleje (locatio conductio operis) Kontrakten hvorved den ene Part (Værksmesteren) forpligter seg til imod Vederlag at frembringe et Arbejdsresultat for den anden (Værksherren). Det, der adskiller Kontrakten fra andre gensidig bebyrdende Arbejdsaftaler, er altsaa, at Arbejderen paatager sig at frembringe et Arbejdsresultat, ikke blot at yde et vist Arbejde.» Distinksjonen mellom verksleie og tjenesteleie samsvarer med distinksjonen i fransk rett mellom «contrat d’entreprise» og «contrat de travail.» Også under engelsk rett kjenner man begrepene «contracts for work» og «contracts of employment».

${ }^{67}$ Se om dette som en egen form for reelle hensyn, Sverre Blandhol, De beste grunner, Oslo 2013 s. 41. 
at kontraktstypene utgjør rasjonelle strukturer forankret i etablert rettstradisjon, som i noen grad bestemmer hvilke prinsipper som må gjelde for en gitt kontraktstype og hvordan. ${ }^{68}$

\section{Nærmere om de alminnelige prinsippenes natur og funksjon i}

\section{kontraktsretten}

Det er åpenbart et nokså forenklet bilde å forestille seg at det finnes et sett naturgitte regler for enhver kontraktstype, og at det å typeklassifisere kontrakten kan likestilles med å trykke på en knapp hvoretter «hele settet av utfyllende rettsregler [kommer] til anvendelse». ${ }^{69}$ Antagelig har vel det heller aldri vært noens mening. ${ }^{70}$ Der vi mangler lovgivning vil man i noen grad være henvist til friere vurderinger. At bakgrunnsretten mangler faste og positiverte regler vil kunne ses som en vektig innvending mot å legge særlig vekt på den. Siden man da er henvist til friere prinsippbetraktninger gir det tilsynelatende et større spillerom for skjønn, og mindre forutberegnelighet enn der man kun forholder seg til det som står i kontrakten. Dette er en innvending som åpenbart har noe for seg. Synspunktet i

\footnotetext{
${ }^{68}$ Hva som er forskjellen på et reelt hensyn og et prinsipp er et eget spørsmål som jeg allerede har vært inne på og også kommer tilbake til nedenfor. Antydningsvis kan vi kanskje si at et reelt hensyn er en rasjonell grunn for en gitt løsning, mens når vi sier at noe er et prinsipp sier vi også at det har en bestemt rettslig forankring.

${ }^{69}$ Andenæs, Kontraktsvilkår (1989), s. 15.

70 Jf. for eksempel Ussing, Aftaler (1950), s. 434: «Skulde der opstaa Spørgsmaal, hvorom der endnu ikke er fastslaaet en Regel, maa Retsudøveren selv opstille Reglen, og maa søge at finde den Ordning, der passer bedst for den paagældende kontraktstype, idet han tager Hensyn til de allerede fastslaaede Regler.
} 
det følgende er likevel at det å gjøre seg opp en mening om bakgrunnsretten for en gitt kontrakt ikke bare har praktisk og teoretisk interesse, men mer fundamentalt at dette alltid er et $n \varnothing d v e n d i g$ element i tolkningsprosessen, noe som skal fors $\varnothing$ kes begrunnet nærmere i det $f \varnothing$ lgende.

Dypest sett må dette begrunnes med de alminnelige prinsippenes natur og funksjon i kontraktsretten. Et første spørsmål her er hva et prinsipp egentlig er. I helt alminnelig forstand har antagelig ikke begrepet prinsipp som sådan noen helt fastlagt betydning, og det brukes også på ulike måter. ${ }^{71}$ En nokså vanlig forståelse er at et prinsipp betegner en generell norm forbundet med grunnleggende hensyn for en type rettsforhold, et mer omfattende rettsområde eller for rettsordenen i alminnelighet. ${ }^{72}$ En innvending som man

\footnotetext{
${ }^{71}$ Det finnes en omfattende litteratur om prinsipper i rettslig argumentasjon, se for nyere litteratur blant annet Graver, «I prinsippet prinsipiell - om rettsprinsipper» (2006), s. 189-221, Jørgen Dahlberg-Larsen og Bettina Lemann Kristiansen (red.), Om retsprincipper, København 2004, Nils Nygaard, Rettsgrunnlag og standpunkt, 2. utgave, Bergen 2004, særlig s. 260 følgende og Markus Jerkø, «En taksonomi over rettslige prinsipper», Tidsskrift for Rettsvitenskap, 2012 s. 1-48.

${ }^{72}$ Se for eksempel Thomas Wilhelmsson, «De allmänna lärorna under trycket från rättens fragmentering och avnationalisering», Retfærd, 2003 s. 32-49, på s. 33 og Nygaard, Rettsgrunnlag og standpunkt (2004), s. 260 følgende. Det fremholdes ofte at prinsipper som en konsekvens av dette normalt har «retningslinjekarakter», det vil si at de i motsetning til regler ikke anviser noe bestemt resultat men kun gir en formodning for at noe skal gjelde dersom det ikke gjelder sterke motstridende hensyn (ofte basert på andre, kolliderende prinsipper). Se blant annet slik Graver, «I prinsippet prinsipiell - om rettsprinsipper» (2006), s. 195, men se også mer skeptisk Jerkø, «En taksonomi over rettslige prinsipper» (2012), s. 24 følgende.
} 
ofte møter på i kjølvannet av rettsrealismen i Norden, er at prinsipper som gjerne kan være basert på sammenfatninger av eller induksjon fra flere konkrete regler ikke har noen selvstendig rettslig kraft eller betydning i seg selv, men primært er av «systematisk og ... pedagogisk karakter ${ }^{73}{ }^{73}$ Etter mitt syn står vi da ikke overfor noe prinsipp i egentlig forstand; det foreligger ingen rettsnorm. I alle fall på kontraktsrettens område synes det også stort sett å være anerkjent at prinsipper utledet gjennom induksjon fra mer konkrete regler er rettsnormer med selvstendig rettslig betydning, selv om det som nevnt kan være litt ulike meninger om hvilken gjennomslagskraft slike prinsipper bør ha. ${ }^{74}$ Som jeg kommer tilbake til nedenfor innebærer slik induksjon og analogi fra mer konkrete regler i lov eller sedvane/rettspraksis, ikke noe annet enn at bestemte reelle hensyn eller sammenfatninger av reelle hensyn anses forankret eller grunnfestet i rettsordenen som «alminnelige prinsipper». ${ }^{75}$ I dette ligger også forklaringen på de alminnelige prinsippenes funksjon, i alle fall i kontraktsretten. Hvis man unnlater å ta stilling til hvilke alminnelige prinsipper som gjelder for et gitt spørsmål, for eksempel ved tolkning av en kontrakt, ignorerer man de reelle hensyn og de avveininger av reelle hensyn som kan ha sementert seg gjennom

\footnotetext{
${ }^{73}$ Graver, «I prinsippet prinsipiell - om rettsprinsipper» (2006), s. 196, og se også Jerkø, «En taksonomi over rettslige prinsipper» (2012), s. 19, som begge er kritiske til et slikt syn.

${ }^{74}$ Se særlig Jerk $\varnothing$, «En taksonomi over rettslige prinsipper» (2012), s. 19-20 med videre henvisninger.

${ }^{75}$ Denne forståelsen er antagelig nokså sammenfallende med det Lilleholt kaller «ferdigbunta reelle omsyn» som er et trekk ved mange tradisjonelle prinsipper i formueretten, se Kåre Lilleholt, «Bruk av reelle omsyn i formueretten» Jussens Venner, 2000 s. 49-60, på s. 53.
} 
rettsordenen som retningsgivende for Iøsningen av det aktuelle spørsmålet. Et eksempel er prinsippet om at heving normalt krever vesentlig mislighold. Dette bygger nettopp på en sementering av avveiningen mellom hensynet til bestillers interesse i å fri seg fra avtalen når han ikke mottar realytelsen på riktig måte eller til riktig tid, og hensynet til yterens interesse i å fastholde en inngått avtale som han både vil ha innrettet seg etter og gjort bestemte oppofrelser for å oppfylle.

Slike alminnelige prinsipper vil i kontraktsretten ofte ha en mer eller mindre «stivnet» karakter. Bestemte konsepter med en mer eller mindre fastlagt betydning kan ha krystallisert seg gjennom praksis og sedvaner eller lovgivning. Der prinsippet er positivrettslig forankret og uttrykt gjennom bestemte konsepter, kan en del av forankringen også være at det inngår som en del av et større konseptuelt system. Et eksempel på dette er forholdet mellom mislighold og risiko. I norsk kontraktsrett anser man gjerne at begrepet mislighold har en normativ komponent som går utover det å konstatere at det foreligger manglende oppfyllelse av en bestemt kontraktsforpliktelse - det forutsetter også at yteren har risikoen for ikke-oppfyllelsen - med andre ord at det ikke foreligger kreditormora. ${ }^{76}$ Dette kan så gi grunnlag for et prinsipielt synspunkt om at kontraktsrettslige sanksjoner eller ansvar, som etter sin art er nærliggende å anse som misligholdsbeføyelser, også forutsetter

\footnotetext{
${ }^{76}$ Jf. Hagstrøm, Obligasjonsrett (2011), s. 327.
} 
mislighold og dermed må anses å innbefatte en risikoreservasjon. ${ }^{77}$ Et konkret eksempel som kan forstås ut fra et slikt synspunkt er en nylig avsagt høyesterettsdom, der et kontraktsvilkår om erstatningsansvar for leietaker for «for all skade eller mangler som skyldes ham selv eller folk i hans tjeneste» nettopp ble ansett å forutsette mislighold fra leietakerens side. ${ }^{78}$

Vurderingsfriheten knyttet til de aktuelle hensynene som ligger under prinsippet vil alltid i større eller mindre grad være bundet opp gjennom de begrepsmessige abstraksjonene som er prinsippets positivrettslige forankring. ${ }^{79}$ Samtidig bringer prinsippene fleksibilitet og dynamikk inn i retten, gjennom de mer alminnelige hensyn som vi ser prinsippet som utslag av og som dermed i en viss forstand fortsatt «lever» i prinsippet. ${ }^{80}$ De positive rettskildene

\footnotetext{
${ }^{77}$ Se for en nærmere drøftelse av dette som et prinsipielt hensyn ved fortolkning av riggkontrakter i offshoresektoren, Alvik, Fartøystjenesteleie (2014), s. 184 følgende.

78 HR-2016-1447-A.

${ }^{79}$ Særlig den tyske obligasjonsretten går langt i slik retning, mens den norske og nordiske tradisjonen har vært preget av en mer pragmatisk tradisjon, se for eksempel Amund Bjøranger Tørum, «Konsekvens i formueretten», Jussens Venner, 2002 s. 314-339. Det er lett å peke på de uheldige sidene av begge retninger hvis de rendyrkes. Rendyrket pragmatisme fører til mangel på konsekvens og forutberegnelighet i rettssystemet. Rendyrket begrepsjurisprudens fører på den annen side til en rett som dyrker det logiske og abstrakte for sin egen del, uten hensyn til den praktiske funksjon retten skal tjene.
}

\footnotetext{
${ }^{80}$ Se slik også Jan Fridthjof Bernt, «Den dynamiske dimensjon i rettskildelæren » i Nybrott og odling: Festskrift til Nils Nygaard på 70 års dagen 3. april 2002, Bergen 2002 på s. 259-272.
} 
som forankrer prinsippet må hele tiden fortolkes i lys av det alminnelige prinsippet, som i en viss forstand «besjelet» av det. Fastleggelsen av innholdet og rekkevidden av et alminnelig kontraktsrettslig prinsipp for en gitt kontraktstype vil dermed rent konkret måtte bestå i en vekselvirkning mellom å ta på alvor de etablerte konsepter som er prinsippets positivrettslige og systemiske forankring, og de grunnleggende normative hensyn og formål som begrunner prinsippet og utgjør dets dynamiske element. ${ }^{81}$

Som eksempel kan vi igjen ta det alminnelige kontraktsrettslige prinsippet om at heving forutsetter vesentlig mislighold. Dette prinsippet kan på rent positivistisk grunnlag utledes gjennom induksjon fra ulike lover som oppstiller et vesentlighetskrav som vilkår for heving. Som en rent systematiserende og pedagogisk øvelse tomt for annet innhold vil dette ha liten verdi. Når vi formulerer vesentlighetskravet som et alminnelig prinsipp har det imidlertid også en normativ komponent, basert på de mer grunnleggende prinsipper eller hensyn i kontraktsretten generelt som det er et utslag av. Denne normative komponenten kan ikke formuleres abstrakt eller generelt på noen måte som er helt presis eller uttømmende. Sagt på en annen måte; hva som er vesentlig kan variere fra en kontrakt til en annen. Vesentlighetsvilkåret sammenfatter at adgangen til heving på den ene side er et utslag av det grunnleggende hensynet til gjensidighet i kontraktsforhold, forankret rettslig i det som ofte betegnes som et eget gjensidighetsprinsipp i kontraktsretten. Når en part ikke oppfyller

\footnotetext{
${ }^{81}$ Her er jeg inspirert av den amerikanske juristen og rettsfilosofen Ronald Dworkin, se generelt Ronald Dworkin, Law's Empire, Cambridge 1986.
} 
sin ytelse svikter også forutsetningen for den andre partens ytelse. På den annen side krever blant annet hensynet til lojalitet og rimelighet og den oppfyllende parts innrettelse og oppofrelser at ikke ethvert kontraktsbrudd gir hevingsrett; kontraktsbruddet må forrykke forutsetningene for hele avtalen på en slik måte at bestilleren har et rimelig krav på å komme fri fra kontrakten. For noen kontraktstyper kan disse hensynene også medføre at man bør operere med et skjerpet hevingsvilkår, typisk at heving bare kan skje der formålet med avtalen blir vesentlig forfeilet som følge av misligholdet. Ut fra en stivnet forståelse av hva som ligger i vesentlig mislighold kunne dette vært ansett som at prinsippet ikke kommer til anvendelse. Men dersom man ser vesentlighetsvilkåret som et mer fleksibelt, dynamisk uttrykk for en avveining av ulike hensyn kan en skjerping av hevingsadgangen også ses som et utslag av det samme prinsippet, riktig fortolket. Man kan se det slik at om et skjerpet hevingsvilkår kan anses gjeldende for en gitt kontrakt på ulovfestet grunnlag må ta utgangspunkt i nettopp de prinsipielle hensyn som begrunner de positivrettslige uttrykk hevingsvilkåret har fått. ${ }^{82}$

Det jeg her kaller prinsipper vil ofte kunne fremstilles som reelle hensyn ved fortolkningen av en lovbestemmelse om heving, eller som «naturlige» forutsetninger partene må ha hatt da

\footnotetext{
82 Jf. den kjente Kure-dommen, Rt. 1922 s. 308. Selv om det ikke er så mange spor av et slikt prinsipielt resonnement i selve dommen, der dette blir begrunnet utfra et forutsetningssynspunkt, har dommen i ettertid blitt tatt til inntekt for det prinsipielle synspunkt at det må gjelde et skjerpet hevingskrav ved tilvirkningskontrakter, som nå er lovfestet i Kjl. § 26.
} 
de inngikk kontrakten. ${ }^{83}$ Samtidig er slike hensyn noe helt annet enn «rettsanvenderens egne vurderinger ${ }^{84}$ Og normalt finner de heller ikke gjenklang i noen faktisk intensjon hos partene da kontrakten ble inngått. Gjennom sin forankring som et rettsprinsipp anerkjent av rettsordenen utgjør slike hensyn derimot normativt tvingende betraktninger ved den konkrete fortolkningen av en faktisk lov- eller avtalebestemmelse. Ved å si at hensynene har en prinsipiell forankring sier vi at de både har rettslig betydning ved tolkningen av konkrete lovbestemmelser som anses som utslag av prinsippet, og potensiell betydning på områder som ikke er lovregulert.

Forstått på denne måten blir det også klarere hvilken betydning de alminnelige prinsippene har i relasjon til individuelle kontrakter. Ved å knytte kontraktstolkningen til en slik antatt bakgrunnsrett bestående av alminnelige prinsipper, selv der retten i liten grad er positivert gjennom lovgivning eller sedvane, stiller vi i virkeligheten et krav om at de pragmatiske betraktninger vi gjør oss om reelle hensyn eller konkret rimelighet i tilknytning til et aktuelt tolkningsspørsmål, normalt må kunne grunngis som utslag av et mer alminnelig prinsipp anerkjent av rettsordenen. For eksempel bør det normalt ha liten betydning at en bestemt tolkning som tilsynelatende følger av en klar ordlyd fører til et konkret urimelig resultat, hvis vi ikke er i stand til å underst øtte en tolkning i samsvar med det konkret rimelige i noe mer objektivt. Det objektive her kan enten være konkrete forutsetninger eller holdepunkter i

\footnotetext{
${ }^{83}$ Jf. slik Kure-dommen, Rt. 1922 s. 308.

${ }^{84}$ Jf. slik også Lilleholt, «Bruk av reelle omsyn i formueretten» (2000), s. 50.
} 
partenes kontraktsforhold, eller at løsningen samsvarer med noe som kan anses som et alminnelig prinsipp. Alminnelige prinsipper strukturerer i så måte hvilke reelle hensyn som må tas i betraktning ved vurderingen av et rettsspørsmål under en kontrakt. Samtidig bringer de også inn et dynamisk element i tolkningen; de gir en basis for å sette kontraktsbestemmelser i system og fortolke dem i lys av de gjennomgående og bærende hensyn i kontraktsretten.

\section{Analogislutninger som grunnlag for «alminnelige prinsipper»}

Det følger av det som er sagt over at å komme frem til at noe følger av et rettsprinsipp, i tråd med min forståelse, er noe annet enn en «fri» vurdering av reelle hensyn. ${ }^{85}$ En vanlig forståelse av reelle hensyn er at det er tale om vurderinger rettsanvenderen står fritt til å foreta innenfor et foreliggende rettsmateriale; rettsanvenderen setter seg så å si i lovgiverens sted og vurderer hvilken regel eller hvilken løsning som i et gitt tilfelle fremstår som den beste. ${ }^{86}$ Når vi sier at noe følger av et prinsipp sier vi derimot at løsningen er resultatet av en erkjennelsesprosess og ikke av en fri vurdering. Basert på et foreliggende

\footnotetext{
${ }^{85}$ Også mange som benytter begrepet reelle hensyn fastholder at reelle hensyn er noe annet enn rettsanvenderens frie vurderinger, se for eksempel Lilleholt, «Bruk av reelle omsyn i formueretten» (2000) og generelt også Blandhol, De beste grunner (2013), s. 22 følgende. Se også for en grundig diskusjon av vurderingsfriheten eller «rettsanvendelsesskjønnet» i rettslig argumentasjon, Synne Sæther Mæhle, Grenser for rettsanvendelsesskjønn, Oslo 2005 særlig s. 71 følgende.

${ }^{86}$ Se Blandhol, De beste grunner (2013), s. 28, med ytterligere henvisninger.
} 
rettsmateriale eksisterer prinsippet allerede, og vi sier endatil at det, riktig fortolket og anvendt, gir tvingende grunner for den løsningen vi kommer frem til. ${ }^{87}$ Også når Høyesterett tolker inn et prinsipp i et foreliggende rettslig materiale, med implikasjoner som ingen kanskje tidligere har sett eller anerkjent, er tolkningen riktignok en kreativ prosess. ${ }^{88}$ Forskjellen er at der den rene «reelle hensyn som vurdering» synsvinkelen insisterer på at Høyesterett fra sitt eget interne perspektiv stod fritt til å komme frem til den løsningen de selv anså burde gjelde som regel på området, krever «prinsippsynspunktet» at løsningen for dommerne må ha fremstått som et $n \varnothing d v e n d i g$ resultat av de rettslige overlegningene de til slutt finner avgjørende. De har «erkjent» hvilke reelle hensyn som er forankret i rettsordenen og hvilken Iøsning disse i det aktuelle tilfellet krever, ikke foretatt en fri vurdering slik lovgiveren kunne ha gjort.

\footnotetext{
${ }^{87}$ Fra en teoretisk synsvinkel kan man i lys av dette spørre om rettslige spørsmål kan ha mer enn en riktig Iøsning. Det klassiske rettsrealistiske svaret er ja. En av bærebjelkene i Ronald Dworkins rettsfilosofi er derimot at det i prinsippet finnes en riktig løsning på alle rettslige spørsmål, se for diskusjon Mæhle, Grenser for rettsanvendelsesskjønn (2005), s. 95 følgende. Og se også for eksempel likeledes Lilleholt, «Reelle omsyn i formueretten» (2000), s. 49: «Eit rettsspørsmål har berre ei løysing som er den beste eller, om vi vil, den rette. Dersom ein ikkje meiner det er til dømes dissensar i kollegiale domstoler meiningslause.»

${ }^{88}$ Noen ganger (men ikke alltid) kan den praktiske forskjellen på disse to synsmåtene også fremstå nokså marginal. Se for eksempel diskusjonen rundt Høyesteretts avgjørelse i den kjente «To mistenkelige personer»saken (Rt 1952 s. 1217) i Nygaard, Rettsgrunnlag og standpunkt (2004), s. 262 følgende.
} 
Som allerede antydet $\mathrm{i}$ avsnittet over er det behovet for å forankre reelle hensyn i noe annet enn våre egne oppfatninger og vurderinger, som også kan anses å begrunne den tradisjonen vi har i norsk og nordisk kontraktsrett med å oppstille alminnelige prinsipper gjennom induksjon eller analogi fra eksisterende lovgivning. ${ }^{89}$ Hvis man ser reelle hensyn primært som vurderinger, og eksisterende lovgivning kun som regler med et positivrettslig begrenset anvendelsesområde, gir det i seg selv liten grunn til å tillegge analogislutninger noen særlig autoritet. Når vi derimot tar som utgangspunkt at enkeltregler ses som utslag av et helhetlig konsistent system bygget på visse alminnelige hensyn, eller prinsipper, gir det analogislutninger mye av den samme positivrettslige forankring og legitimitet som selve lovregelen.

En hovedgrunn til å legge vekt på analogislutninger er dermed hensynet til konsistens og likhet. Når de hensynene eller prinsipielle synspunktene som begrunner en gitt regel i like stor grad gjelder for andre tilfeller enn de regelen direkte omfatter, tilsier konsistenshensyn at regelen anvendes analogisk. Mer fundamentalt kan dette også anses rotfestet i den grunnleggende rettferdighetsbetraktningen at like tilfeller skal behandles likt. ${ }^{90}$ Samtidig gir

\footnotetext{
${ }^{89}$ Tradisjonelt er det kjøpsloven som her har stått i en særstilling som grunnlag for å utlede mer alminnelige prinsipper, sammen med og på grunnlag av en mer fellesnordisk obligasjonsrettslig teori inspirert av kontinentaleuropeisk tradisjon. Se nærmere for eksempel Hagstrøm, «Den norske obligasjonsretts historie» (2003), s. 161, og Tørum, «Nordisk obligasjonsrett og dens betydning for norsk kontraktsrett» (2007), s. 563.

${ }^{90}$ Særlig Dworkin går langt i å fremheve dette som rettstankens essens gjennom sin teori om «law as integrity», det vil si det som blant annet skiller rett fra moral og rettferdighetsoppfatninger. At rettstanken grunnleggende
} 
konsistens grunnlag for forutberegnelighet. Når en rettslig løsning er fastslått for ett tilfelle eller på ett område, kan man da samtidig gå utfra at det samme vil gjelde for andre tilfeller og områder, og slik sett ha et grunnlag for å forutberegne sin rettsstilling. Det å basere seg på analogier fra lover kan imidlertid også ses som utslag av lojalitet til lovgiver. Ved å gi loven analogisk anvendelse på tilfeller som riktignok faller utenfor lovens direkte anvendelsesområde, men likevel omfattes av dens prinsipielle begrunnelse, viser domstolene lojalitet til lovgivers intensjoner også når de er konfrontert med spørsmål som ikke er lovregulerte. En slik betraktning om hva som utgjør lovgiverviljen er naturligvis en abstraksjon, som likevel utgjør en binding for tanken i det at en aktuell rettslig løsning for å være gangbar må kunne passere som samsvarende med intensjonen bak den aktuelle loven. I kontraktsretten må det nok likevel anses at hensynet til lovgiverviljen er underordnet hensynet til konsistens og forutberegnelighet, i alle fall når det gjelder deklaratorisk lovgivning, siden grunnlaget for anvendelse av en lovregel i et gitt kontraktsforhold normalt må være at den kan anses å gi et uttrykk for rimelige normalforutsetninger.

Ved å anvende en kontraktsrettslig lovbestemmelse analogisk, er det vi gjør egentlig bare å si at den må ses som utslag av et mer alminnelig prinsipp om rimelige normalforutsetninger

sett består i et krav til «integrity» fremstilles av Dworkin som alternativet til ren positivisme og ren pragmatisme, og innebærer et overordnet bilde av retten som en autonom ideell helhet («a community of principle»), der autoritativt rettsstoff alltid må fortolkes i lys av helheten og rettssystemets grunnverdier. Tolkning består dermed i å fremstille retten i hvert enkelt tilfelle som «the best it can be» i lys av slike grunnverdier. Se nærmere Dworkin, Law's Empire (1986), for eksempel s. 95-96. 
for en større gruppe av kontrakter enn den loven uttrykkelig gjelder. Lovbestemmelsen utgjør en positivrettslig forankring av prinsippet, som det imidlertid er overlatt til rettsanvenderen å finne ut av og avdekke. Analogislutninger kan dermed anses som en form for tolkning. Spørsmålet er imidlertid ikke hvordan den aktuelle regelen skal tolkes, men derimot hva som skal anses som dens bakenforliggende begrunnelse. Her vil det kunne tenkes at regelen dels er begrunnet i forhold og hensyn som er spesielle for det aktuelle livsområdet den regulerer, og dels mer prinsipielle hensyn knyttet til ytelsens grunnleggende natur. Det sentrale tolkningsspørsmålet blir dermed å skille ut og avdekke «det alminnelige» i regelen fra det som er særegent for akkurat det livsområdet regelen direkte gjelder. Man kan naturligvis også tenke seg analogislutninger fra annet enn lovbestemmelser, for eksempel der vi har en etablert sedvanerettslig regel på et gitt rettsområde.

Ofte vil det prinsipielle vi leter etter ha forbindelse med de naturlige kontraktstypene som er omtalt over. Hvis vi ser så vidt ulike avtaler som reisebefraktning, entreprise og brøyting og salting av veier, som undergrupper av en og samme prinsipielle kontraktstype (verksleie), vil det for eksempel kunne gi et prinsipielt argument for at liggetidsbetaling i havn, ${ }^{91}$ eller kompensasjon for høyere forbruk av salt, ${ }^{92}$ i alle tilfelle må ses som vederlag for tilleggsarbeid og ikke erstatning.

\footnotetext{
${ }^{91}$ Solvang, Forsinkelse i havn (2009), s. 355.

92 Jf. Rt. 2010 s. 1345 (Oslo Vei), som også er et godt eksempel på at det kan være ulike synspunkter på vekten av slike prinsipielle argumenter. Her fant flertallet at uttrykket «merutgifter» i kontrakten måtte fortolkes som
} 


\section{Forholdet mellom alminnelige prinsipper og tolkning av den enkelte avtale}

Selv om det utfra slike betraktninger som er gjort over er mulig å oppstille alminnelige prinsipper for kontraktstypen, vil det likevel kunne være en innvending at kontraktene selv tilsier at bakgrunnsretten i liten grad er anvendelig. At det ikke er noen automatikk i at det vi anser som bakgrunnsretten for en gitt kontraktstype skal anvendes, følger allerede av det mest grunnleggende prinsippet rettsordenen anerkjenner for avtaler i alminnelighet, nemlig prinsippet om avtalefrihet. I dette ligger at en kontrakt må tolkes i samsvar med det som følger av en klar ordlyd, når det ikke er holdepunkter for at partene må ha ment noe annet, selv om det skulle være slik at en annen Iøsning følger av bakgrunnsretten. ${ }^{93}$ I det følgende skal jeg ta for meg to potensielle innvendinger som utfra dette kan tenkes mot å legge vekt på alminnelige prinsipper ved tolkning av individuelle kontrakter.

en form for erstatningskrav slik at entreprenøren kunne kreve sine faktiske kostnader. I den aktuelle saken fremstod nok det også som det konkret rimeligste resultatet, siden entreprenøren i forhandlinger med sin underentrepren $\varnothing$ r hadde fått denne til å frafalle kravet om ekstrabetaling for utleggingskostnader. Mindretallet la derimot et mer prinsipielt synspunkt til grunn og fant at det avgjørende var «av hvilken art kravet er»og at entreprenørens krav her måtte anses som et vederlagskrav noe som tilsa at han også skulle ha kompensert utleggingskostnadene, jf. avsnitt 82.

\footnotetext{
${ }^{93}$ Se nærmere om bakgrunnsrettens gjennomslagskraft ved klar og uklar ordlyd, særlig Høgberg, Kontraktstolkning: særlig om tolkningsstiler ved fortolkning av skriftlige kontrakter (2006), henholdsvis s. 193 og s. 208 følgende.
} 
Den første mulige innvendingen er at vi kan stå overfor kontrakter som er detaljert utformet med presise vilkår, og at de enten ikke er utformet med noen bakgrunnsrett i tankene, eller at de må fortolkes slik at de for alle praktiske formål er ment å være uttømmende og dermed erstatte bakgrunnsretten. ${ }^{94}$ Etter mitt syn er ikke dette i seg selv noen vektig innvending mot at bakgrunnsretten vil kunne være både relevant og avgjørende for hvordan bestemte tolkningsspørsmål må Iøses, selv der kontraktene inneholder sine egne svært grundige og detaljerte vilkår. At en kontrakt kan inneholde så detaljerte og presise regler at bakgrunnsretten blir trengt i bakgrunnen er en ting. ${ }^{95}$ Det kan også tenkes at dette medfører at bakgrunnsretten for en del spørsmål blir lite praktisk relevant. Men noen prinsipiell innvending mot bakgrunnsrettens relevans gir likevel ikke dette. Der kontrakten er uklar - og i enhver kontrakt og nesten ved tolkningen av enhver kontraktsbestemmelse vil det kunne oppstå uklarhet - gir det liten mening å holde fast ved at kontrakten er uttømmende. ${ }^{96}$ Fordi kontrakten er uklar er den jo nettopp ikke uttømmende. Den har da ikke entydig fastlagt noen bestemt løsning for det aktuelle tvilsspørsmålet. Av samme grunn gir det liten mening å insistere på at det vil være best i samsvar med et hensyn til forutberegnelighet å anse at visse typer kontraktsreguleringer er forutsatt å være uttømmende. Dette bygger på en forutsetning om at kontrakten Iøser de aktuelle spørsmålene. Men hvis kontrakten er uklar

\footnotetext{
${ }^{94}$ Se for eksempel Erlend Haaskjold, Kontraktsforpliktelser, 2. utgave, Oslo 2013 s. 350 følgende.

${ }^{95}$ Jf. slik for eksempel Sondre Dyrland, Det nye gassmarkedet, Bergen 2008 s. 29.

${ }^{96}$ Dyrland, Det nye gassmarkedet (2008), s. 30.
} 
svikter jo nettopp denne forutsetningen; da gir ikke kontrakten selv noen entydig løsning. $\AA$ tolke kontrakten i lys av bakgrunnsretten vil her kunne bidra til bedre forutberegnelighet enn alternativet, som er en tolking utelukkende basert på friere forutsetningsbetraktninger og rimelighet.

En nyansering av det som egentlig er den samme innvendingen som over kunne være at der ordlyden i utgangspunktet fremstår som klar, vil likevel det at noe annet følger som en formodning etter bakgrunnsretten i seg selv kunne skape en uklarhet, som utviskes hvis bakgrunnsretten tenkes utelukket. Argumentet ville da måtte være at alene det å forutsette at kontrakten er uttømmende utelukker denne formen for uklarhet. Heller ikke dette er noen overbevisende innvending etter mitt syn. Hvis en Iøsning isolert synes å følge av ordlyden mens noe annet følger av bakgrunnsretten, er det normalt ikke bakgrunnsrettens løsning i seg selv som skaper uklarheten, men derimot at ordlydens Iøsning fremstår som så lite fornuftig, urimelig eller ubalansert at det er vanskelig å tenke seg at partene virkelig mente å avtale noe slikt. Her vil bakgrunnsrettens Iøsning kunne gi et ytterligere holdepunkt for å anta at det kan de da heller ikke ha ment, og gi støtte for en annen tolkning enn det ordlyden isolert sett tilsier. Men selve uklarheten var der allerede. I motsatt fall vil jo ikke det at noe annet følger av bakgrunnsretten i seg selv ha betydning, da vil det jo være klart at partene har avtalt noe annet.

Den andre potensielle innvendingen kan derimot prinsipielt sett ha mer for seg, nemlig at det å basere seg på prinsipielle utledninger fra bakgrunnsretten kan stenge for tilstrekkelig pragmatiske og forutsetningsnære tolkninger basert på konkrete holdepunkter i det enkelte kontraktsforhold. Bakgrunnsretten vil jo, som nevnt over, måtte fastlegges med 
utgangspunkt i alminnelige prinsipper og etablerte konsepter uten tilknytning til partene, blant annet under hensyn til system og konsistens på det aktuelle rettsområdet. Alternativet kunne være at man heller la vekt på friere og mer pragmatiske betraktninger av hva som, alle forhold tatt i betraktning, fremstår som den beste og rimeligste løsningen i det enkelte kontraktsforhold. Der det finnes holdepunkter i det enkelte kontraktsforhold for å si noe om hvilke forutsetninger partene rimeligvis må ha hatt da de inngikk kontrakten (forutsetningstolkning), må det åpenbart normalt tillegges vel så stor betydning som mer prinsipielle utledninger fra bakgrunnsretten. Og det at en løsning fremstår som klart mest rimelig eller kommersielt fornuftig vil gjerne være et sterkt argument for at avtalen må fortolkes i samsvar med dette.

Et vesentlig poeng som likevel i stor grad imøtegår dette som en prinsipiell innvending, er at de fleste av de «alminnelige prinsippene» vi kan finne forankring for i bakgrunnsretten på ulovfestet grunnlag, nettopp må knytte an til hva som i alminnelighet vil være naturlige og rimelige forutsetninger i den typen kontrakter vi ser på. Når vi skal fastlegge hva som følger av bakgrunnsretten, forutsetter det gjerne at vi først tar stilling til hva som er avtalt i den enkelte kontrakt om hovedytelser, funksjonsfordeling og gjensidighetsforutsetninger i kontraktsforholdet. Å resonnere på grunnlag av alminnelige prinsipper betyr ikke å basere seg på mekaniske analogibetraktninger eller rene deduksjoner fra abstrakte begreper og prinsipper. Det er ikke (eller bør ikke være) tale om noen form for ren begrepsjurisprudens hvor logiske abstraksjoner overtar all styring over tanken. Ved å si at noe er et alminnelig prinsipp identifiserer vi egentlig visse hensyn som vi anser har en forankring og positiv legitimering i kontraktsretten som en tenkt, konsistent helhet, men vi sier ikke at prinsippets 
innhold med det er endelig determinert. Prinsippet må gis et innhold i hvert konkrete tilfelle. Her må vi ta utgangspunkt i de positivrettslige uttrykk prinsippet har fått gjennom eksisterende lover, rettspraksis og sedvaner, men disse må likevel fortolkes i lys av de grunnhensyn vi leser inn i prinsippet som dets grunnlag og begrunnelse. Slik sett utgjør den kontraktsrettslige bakgrunnsretten i den betydning jeg tillegger den her, i første rekke et konseptuelt og prinsipielt rammeverk for forståelsen av konkrete kontrakter. I varierende grad gir den også et visst grunnlag for å oppstille mer eller mindre klare formodninger for en del spørsmål, som kan få betydning både som grunnlag for tolkning og utfylling av individuelle kontrakter. Den gir derimot som regel ikke grunnlag for å utlede faste og forutinntatte løsninger på alle de problemstillinger som kan oppstå i kontraktsforholdene, og som kontraktene normalt også selv regulerer. 